\title{
Views of the Elderly Regarding the Behavior by His Family Members
}

\author{
Siddique $\mathrm{AB}^{1}$
}

\begin{abstract}
This was a Cross-sectional Study conducted in urban area of Dhaka city corporation, During the Period of 1 st January to 30th June 2009, with a view to assessing the views of elderly regarding the behavior by his family members. A total of 150 respondents of both sexes 60 years and above were interviewed of which $60 \%$ were males and $40 \%$ were female, $57.33 \%$ were in the age group of 60-69 years. $10 \%$ were illiterate $90 \%$ were from literate group. Among the respondents $90.66 \%$ were Muslim, 34\% were retired, 46\% came from joint family, most of the respondents family income above 10000 thousand taka per month, 58\% of the respondents were neglected by family members, $71.33 \%$ of the respondents were not get properly take care from family members, and $66 \%$ were unhealthy. Among the major health problems $10.66 \%$ had diseases of bones \& Connective tissue, 9.33\% general weakness, 8\% GIT problems, 6.67 $\%$ had cardiovascular diseases, 4.67\% had respiratory diseases. and 3.33\% had diabetic, The study shows that the respondents were deprive from take care of their family members due to some factors, which include family members have no time (76\%), they are busy (80.67\%), no earning capacity (56.67\%), The study revealed that $64 \%$ of the respondents were not respected, $34 \%$ were not take part in familial decision making, $44.67 \%$ were never seeking advice by family members, $61.33 \%$ some times take part in familial program and elderly experience were not respected $69.33 \%$.In this study we found that $80.66 \%$ of the respondents feel lonely, $73.33 \%$ of the elderly not satisfied according to current behaved and Almost 100\% respondents want soft and polite behaved and shelter during old age and want all kinds of support requiring elderly life leading.
\end{abstract}

The findings of the present study showed that the elderly people were unhappy and not satisfy to take care of their family members, their loneliness and misery is indescribable and suffering from different health \& mental problems.

1. Dr. Abu Bakar Siddique, MBBS, MPH

Medical Director

Euro-Bangla Heart Hospital

5/7, block-d, lalmatia, Dhaka1207
It is considered that the findings of the study will not only help as guideline for some preventive program, but also serve as useful basis for future step, research and planning.

\section{Introduction}

Aging is a natural process. Old age is an incurable disease, but more recently, sir James sterling Ross commented; You do not heal old age. You protect it; you promote it; you extended it." These are infecting the basic principles of preventive medicine. Old age should be regarded as a normal, inevitable biological phenomenon. ${ }^{1}$

A person belonging to the age of 60 years and above is regarded as elderly person in Bangladesh. it is an emerging issue in Bangladesh. ${ }^{2}$ The course of population aging is now worldwide and flows freely into social and economic support system, which is directly influenced by the changing age structure. In the context of Bangladesh, rapid socioeconomic and demographic transformation mass poverty, decline social and religious values, the influence of western and modern culture, rapid urbanization and other similar factors are responsible for waning the traditional extended family and community based care system of the mainstream society ${ }^{3}$. Contemporary social disorganization theory has its roots in Durkheim who argued that the process of modernization and urbanization creates communities that lack social integration. The work of wirth was also a precursor to social disorganization ${ }^{4}$. Along with modernization and urbanization, different studies have generally acknowledged that the traditional form of support for older people in Bangladesh is weakening due to several causes e.g. a decrease in land availability, an increase in women's participation in the labor market, migration of children to urban centers, and overall impact of pervasive poverty ${ }^{5}$. An expert group meeting of the international institute on aging identified a similar reason behind the erosion of community based support systems. ${ }^{6}$ On the other hand, religious trusts and charitable institutions are struggling to continue their welfare activities for the older people for want of financial support 
from the public, besides a change in their out look and social behavior ${ }^{7}$. As community support and involvement toward older peoples concern is declining, it is automatically shifting to the governments. Such reality has created extra pressure on national economy in many developing countries and many of its older citizens many have died without care and support ${ }^{8}$.

Demographic projections show that the older population will look dramatically different over the next few decades. The press is constantly reminding us that a dramatic increase in the age of our population over the next 30 or so years will cause the health care system to collapse, economics to crumble under the strain of pension demands and the disintegrating family and community to buckle under increasing care commitement. ${ }^{9}$

The average life span of people every where including Bangladesh has shown an increase in last few decade due to the world wide progress of public health and Phenomenal develop in technology. So that the number of elderly population increasing at a faster rate. Bangladesh Bureau of statistics prepared a table showing population projection of the country (1990-2025). In 1995 total population $118321 \times 1000$ and $60+$ aged is $5.26 \%$; in 2005 total population $137865 \times 1000$ and $60+$ aged is $6.18 \%$ : and in 2010 the total population will be $147563 \times 1000$ and $60^{+}$ aged will be 6.87 . The aged population in Bangladesh is growing both in absolute number and as a percentage of total population, and one in every six would be elderly person. ${ }^{10}$

In 2000, the aging index was 12.8 , and it will increase to 29.8 percent and 72.9 percent in 2025 and 2050, respectively. Although the total dependency ratio of population of the country will come down from 71.9 percent in 2000 to 50 percent and 49 percent in 2025 and 2050, respectively, the old age dependency ratio will be tripled. It will increase from 5.4 percent in 2000 to 7.8 percent and 16.2 percent in 2025 and 2050 respectively, which will affect the demographic structure ob Bangladesh. ${ }^{11}$ If the development planners do not fully apprehend this emerging problem in time, adopt an appropriate national policy and prepare a plan well in advance, the developing country like Bangladesh with scarce resources will have to face a major challenge in providing health care facilities and social securities to the vast number of aged persons ${ }^{10}$. So that the elderly peoples are of significant group of population in our national life. They belong to the category of our grand father/mother, our parents, uncle ,aunt elderly brothers/sister and relatives who once in their prime life worked very hard to raise their families, developed there children and dependent and contributed to social and national development.
In the traditional joint family or extended family system of the country the elderly people used to enjoy respectable and honorable life in the past. But this family pattern is in the process of disintegration. Now days in the face of up coming nuclear family pattern, urbanization, migration economic hand ship, decline social values and other factors. This changing situation of socioeconomic condition causing to the life of elderly very difficult and so pathetic. They suffer from various diseases, and mental problems. Man (company), money, medicine, food , clothes and others life supportive materials are not available to them. Aloneness is only company in every moment. Most of the family members rough behaved to them. We do not support elderly as our father, mother, uncle, or grand father. We do not want to understand them. The elderly feels they are burden to their family. They need human consideration, proper health care and facilities and social securities. Therefore the society and the state should maintain necessary condition. They need company to share their views and to enable the elderly people to pass the remaining life time in happiness and satisfaction.

With the above situation the thinking (views) of elderly is different. They want good behavior and demand to enjoy as other family members. So the views of elderly should be known to us. That why I want to study "views of elderly regarding the behavior by his family members". With this study has been carried out to asses views of elderly, and identify the problems and sufferings of elderly people and to identify etiological factors responsible to that and to make a suggestion for improving their condition and finally to make an advice from elderly people to socio economic development.

\section{Materials \& Methods}

This was Descriptive type of cross sectional study was carried out in the urban area of Dhaka City Corporation during the period of January to June 2009.

The elderly people who fulfill the inclusion criteria and who are interested to take part in research work ,total 150 person are selected purposively for interview with structure and Semi structure questionnaire . Data was collected from elderly founded in morning walk in Ramna garden, Dhanmondi lake, probin hitoyshi hospital ,opd patients in Ibn sina hospital Dhanmondi, After collection of data it was checked, edited, verified and a master table was prepared. The data was then compiled \& tabulated to key variables. Simple statistical analysis of these variables was done with scientific calculators. The data were then analyzed by a computer through SPSS programmed version 6 according to the variables to fulfill the objectives of the study. 
Inclusion Criteria: Age 60 years and above. Who are willingly to participate in the study. Who have blood related family members. Who residing in Dhaka City Corporation .

Exclusion Criteria: Age not below 60 years . Who are not interested to participate in the study. Who have no blood related family members. Who are not residing in Dhaka City corporation

\section{Results}

Among the 150 respondents, $60 \%$ were male, $40 \%$ were female. $90.66 \%$ were Muslim, $4.67 \%$ were Hindus \& Christian were 2.67 percent. $10 \%$ of the respondents were illiterate in which $5.33 \%$ were male and $4.67 \%$ were female, $24 \%$ up to primary level, 30\% secondary level and S.S.C $16.67 \%$ were male and $13.33 \%$ were female. It was observed that about $57.33 \%$ were in age groups 60 69 years followed by $20 \%$ in $70-79$ years and $19.33 \%$ in 80-89 years. The lowest groups were in $3.33 \%$ in $90+$ age group. Among the respondents 44\% had 5-6 family members, $26.67 \%$ t had 7-8 family members, $19.33 \mathrm{had}$ 9+ family members, Among 150 respondents, about $34 \%$ were retired, $20 \%$ were house wife, $10 \%$ unemployed and $13.33 \%$ were business and about $14 \%$ had job, rest of day labor and others. Out of $150,31.33 \%$ had monthly family income tk. 10000/- 15000/, 24.67\% had tk 15000/$20000 /$ and $21.33 \%$ had tk 20000-25000/ per month and $22.67 \%$ had above $25000 /$ month family income. The study revealed that the family members of elderly $80.67 \%$ were busy, in household purpose $20 \%$ elderly asking for decision making, 46\% had sometimes role, $34 \%$ had no role about decision making.

Table 1: Participation of elderly in family program. $(n=150)$

\begin{tabular}{ccccc}
\hline No. & $\begin{array}{c}\text { Participation in } \\
\text { family program }\end{array}$ & $\begin{array}{c}\text { Male No. } \\
(\%)\end{array}$ & $\begin{array}{l}\text { Female } \\
\text { No. }(\%)\end{array}$ & $\begin{array}{c}\text { Total No. } \\
(\%)\end{array}$ \\
\hline 1 & Some times & $57(38)$ & $35(23.33)$ & $\begin{array}{c}92(61.33 \\
\%)\end{array}$ \\
2 & Always & $20(13.33)$ & $15(10)$ & $\begin{array}{c}35(23.33 \\
\%)\end{array}$ \\
3 & None & $13(8.67)$ & $10(6.67)$ & $\begin{array}{c}23(15.34 \\
\%)\end{array}$ \\
4 & & & & $60(40)$ \\
\hline
\end{tabular}

Among the respondents 61.33 percent some times participant and. 15.33 percent not participant in family program. Among the some times participant 38\% were male and $23.33 \%$ were female.
Table 2: Valued of past experience of elderly $(n=150)$

\begin{tabular}{ccccc}
\hline No. & $\begin{array}{c}\text { Past } \\
\text { Experience }\end{array}$ & $\begin{array}{c}\text { Male } \\
\text { No }(\%)\end{array}$ & $\begin{array}{c}\text { Female } \\
\text { No }(\%)\end{array}$ & Total (\%) \\
\hline 1 & Respected & $30(20)$ & $16(1.67)$ & $46(30.67 \%)$ \\
2 & Neglected & $60(40)$ & $44(29.33)$ & $104(69.33 \%)$ \\
3 & Total & $90(60)$ & $60(40)$ & $150(100)$ \\
\hline
\end{tabular}

Past experience of the elderly was not respected 69.33 percent. Among the neglected past experience $40 \%$ were male and $29.33 \%$ were female.

Table 3: Attitude of the family members towards respondents. $(n=150)$

\begin{tabular}{llccc}
\hline No. & \multicolumn{1}{c}{ Attitude } & Yes & No & Total \\
\hline 1 & $\begin{array}{l}\text { Insulted by } \\
\text { family members }\end{array}$ & $25(16.67 \%)$ & $125(83.33 \%)$ & 150 \\
2 & $\begin{array}{l}\text { Respected by } \\
\text { family members }\end{array}$ & $54(36 \%)$ & $96(64 \%)$ & 150 \\
\hline
\end{tabular}

Among the respondents 16.67 percent were insulted by family members. 64 percent of the respondents are not respected. Among the participant 58\% of the respondents neglected by family members. And $71.33 \%$ of the respondents were not satisfied for take care by their family members.

Table 4: Factors of improper care of the elderly people. $(n=150)$

\begin{tabular}{llccc}
\hline & Barrier to look after & \multicolumn{1}{c}{ Yes } & No & Total \\
\hline 1 & $\begin{array}{l}\text { No time due to } \\
\text { busyness }\end{array}$ & $114(76 \%)$ & $36(24 \%)$ & 150 \\
2 & $\begin{array}{l}\text { Family income is } \\
\text { not good }\end{array}$ & $38(25.33 \%)$ & $112(74.67 \%)$ & 150 \\
3 & No earning capacity & $85(56.67 \%)$ & $65(43.33 \%)$ & 150 \\
4 & Bad relation & $29(19.33 \%)$ & $121(80.67 \%)$ & 150 \\
5 & $\begin{array}{l}\text { Property have } \\
\text { distributed }\end{array}$ & $35(23.33 \%)$ & $115(76.67 \%)$ & 150 \\
6 & $\begin{array}{l}\text { Less religious } \\
\text { believe 50(33.33\%) }\end{array}$ & $100(66.67 \%)$ & 150 \\
\hline
\end{tabular}

About improper care, $76 \%$ t of the family members can not take care of elderly due to busyness, $56.67 \%$ had no earning capacity, $25.33 \%$ had low family income.

Table 5: Physical status of Respondents $(n=150)$

\begin{tabular}{lcccc}
\hline No. & Physical status & Male & Female & Total no (\%) \\
& & No. $(\%)$ & No. $(\%)$ & \\
\hline 1 & Apparently & $30(20)$ & $21(14)$ & $51(34)$ \\
& healthy & & & \\
2 & Un healthy & $60(40)$ & $39(26)$ & $99(66)$ \\
& Total & $90(60)$ & $60(40)$ & $150(100)$ \\
\hline
\end{tabular}


About physical 66 percent of them were un healthy. Among the unhealthy $40 \%$ were male and $26 \%$ were female.

Table 6 Distribution of respondents by their current morbidity

\begin{tabular}{clcc}
\hline No. & Morbidity & Frequency & Percentage \\
\hline 1 & CVD & 10 & 6.67 \\
2 & Weakness & 14 & 9.33 \\
3 & Paralysis & 5 & 3.33 \\
4 & Nervous and & 5 & 3.33 \\
& mentral & & \\
5 & Breast & 5 & 3.33 \\
& disease & & \\
6 & Hydrocele & 1 & 0.66 \\
7 & RTI & 7 & 4.67 \\
8 & Kidney & 2 & 1.33 \\
9 & ENT & 6 & 4 \\
& Problems & & \\
10 & Skin disease & 3 & 2 \\
11 & Bones and & 16 & 10.66 \\
& joints & & \\
12 & Reproductiv & 8 & 5.33 \\
& e system & & \\
13 & GIT & 12 & 8 \\
14 & Diabetic & 5 & 3.33 \\
& Total & 99 & 66 \\
\hline
\end{tabular}

Table 6 shows the most frequent complaints was connective tissue disease $(10.66 \%)$, followed by General weakness $(9.33 \%)$, GIT disturbance $(8 \%)$, Cardio vascular disease $(6.67 \%)$, Reproductive disease (5.33\%), RTI (4.67\%) and ENT problems were (4\%).

The study observed that out of 150 respondents 80.66 $\%$ feel lonely of which $48.66 \%$ were male and $32 \%$ were female. Satisfaction due to behavior, $73.33 \%$ of the respondents were not satisfied to their family members of which $44.67 \%$ were male and $28.66 \%$ were female. $100 \%$ of the respondents wanted soft and polite behave and wanted shelter and all support during old age.

\section{Discussion}

The Problems of the aged are multiple; medical and health psychological financial with assurance of good quality of life and security and good terminal care. The aged are not foreigner or aliens they are the senior citizens who have worked to bring the young generation to meaningful productive status they have guided individual families raise their level of socioeconomic security they have added spiritual approach to life in the community and have contributed their best in the national development and progress.
The community owes a debt of gratitude to them certainly continue to consider them useful and respected citizens.An important point to note is that living arrangements are not indicative of the care and support that is received by parents. For instance, living in an extended family system with one is children Is no guarantee that adequate care and economic support are being provided, and living Independently does not mean that one is needs are not being met by family members. 12

Bangladesh will have a steep rise in its older population in the coming years. With an estimated population of about 147 million people, Bangladesh still ranks 129 by percentage of population aged 60 and over ${ }^{13}$. Because of policies developed for the older population have often failed to take the special concerns of the elderly into accounts. This study was carried out in order to information on Views of elderly, the Socio-economic. functional and health problems and their health care needs so that emphasis on these diverse needs could be given by policy makers, planners and service providers.

The mean age of the respondents of this study was 71.38 years. About 64 Percent of the elderly were depended on their family members for their financial support and social security. The vulnerability of elderly people is also reflected in the higher burden of ill-health and disability. ${ }^{14}$

A substantial proportion of widows were found living alone compared to elderly living with children signifies strong emotional and economic interdependence culture and religious values expressing responsibility for the care of the parents in their old age. On the other hand, the number of elderly widows living in isolation and spouse living together in spite of having caring children are increasing due to poverty auto migration of the children and decorating religious values of the family ties and social status. Similar study in India revealed that older woman than men were loosing their status within the family as result of widowhood and economic despondency upon their family's. ${ }^{15}$ Friction between daughter in law and mother in law was also reported to be a stress on extended and joint families in Pakistan. ${ }^{16}$ In Britain report of 1993 revealed 50 percent of the people over 75 years lived alone due to older people experiencing divorce and 65 percent of women over 75 years are widows ${ }^{17}$. The great majority of the respondents were residing in their own house or that of a child without payment. This dependency on children increases if they do not posses their own houses or have a state of widowhood. 
Individual lifestyle, gene cum health influences to a great extent the reaction to the changes. Biological aging and impairment processes which are highly influenced by in-dividual socioeconomic,psychological, and physiological factors occur constantly and defer among individuals. It is important to stress that these factors affect individuals differently ${ }^{18}$.

The overall average size of the household was 5-6 and most of female elderly people were found taking part in actively in household works. The older populations are neither counted in the labor force or in economic contribution to their societies. But if given a serious thought they could make invaluable. Contribution to socio-economic development through their roles in the family and in the community. Even in old age both men and women can continue to remain economically active as long as their health permits engaging in care of grand children and frail spouses and in family enter prizes such as raising cattle poultry etc. which may be a big cash side line for the families.

Feeling of loneliness is the result of lack of social support. This was found more prevalent among the lower educational level; participation in family decision making indicates an individual exercise of authorization and influence over other members of the family and at the same time ensure economic and social support in old age. These forms of power come into play through the possession of income flows or ownership of property / lands. The elderly male members usually become the owners of the lands through inheritance while females remain economically dependent upon males (husband or sons) thus in this study comparatively higher proportion of females than males reported their opinion were not sought in making decision concerning family affairs .As ageing is not a disease, but because of the challenges that older people face, and with consequent loss of functional, physical and mental capacities they are unable to manage on their own at home. With the decline or loss of the capacities, it becomes difficult to manage with the activities of daily living (ADL). This may lead to institutional care where round the clock care and help in activities of daily living (ADL) are pro-vided. Problems with physical activities of daily living (ADL) among the respondents have been increasing with increased age. Bathing is most common activity needs help similar finding were reported in a study in Thailand and another in USA Respondents having urinary incontinence reported only minor degree for which medical care was rarely sought. The proportion of elders able to perform these activities with difficulty increases significantly with advance of age and the significant gender differences was found for the year's groups.
According to the classification of respondents based that majority were independent for doing their daily activities.

The right balance would be to make the elderly feel that she/ he is an essential part and parcel of the family. Encourages them to be independent with in their capacity help keep them usefully occupied and maintain contact with their friends and relatives. The elderly in such happy circumstances would do every thing in their power to reciprocal to the young generation These modalities are the keys to successful coexistence of the young and old in the family unit.

The care one expends on the elderly apart from being a social and human obligation and duty is an investment in one's future. The child of to day is the youth of tomorrow and the youth of to day is the Elderly' of another tomorrow. Let us build a Shangri- La in every one of our homes not only for those elderly for whom we care but also for us in the twilight's years of our life.

From the above study it may be concluded that males predominate over females. Majority of the elderly was below the age of 69 years \& was literate. Most of them were from the income group $>$ TK 10000 per month. Majority of the elderly were either retired or unemployed and housewife. Most of them from a joint family of 7-8 members. Only a few of the elderly had self-income.

Regarding the knowledge about geriatric diseases, it was found that the literate group knew about the geriatric problems \& about the social activities .But the literacy rate among the elderly is lower than national average $^{13}$ As people get older, the ageing process sets in Starting at middle age, functions of the body become susceptible to constant wear and tear.

There is anoverallweakening in physical and mental capabilities (Patience 2005). As people reach the height of growth and development in their $20 \mathrm{~s}$, transition time sets in and towards the second half of life, people are at higher risk of health challenges with various functions of the body as well as chronic diseases. ${ }^{19}$

As the study was conducted also at the OPD, most of the respondents were found suffering form various health problems e.g .nutritional problems, arthritis, cardiovascular diseases, respiratory disease, vision problems, hearing problems, GIT problems etc. In both the sexes, majority was found suffering from arthritis, Vision problem was another major problem among the elderly \& held a large percentage followed by hearing problem \& cardiovascular diseases. 
The analysis from the research articles showed that malnutrition among older people in living in the institutional care may be attributed to several factors. These includes cognitive decline,changes in biological cum physio-logical functions, and decreased appetite. Other factors include psychological and socio challenges like depression, life event and loneliness, drug/medication usage, dental problems, and gastrointestinal track disorder. Lack of knowledge of nutrition and non-caring attitude of care personnel also increase this risk of malnutrition.

Regarding Behavior of the family members, it was found that most of the family members do not well behaved to their elderly as for reason family members are very busy, they have no enough time for elderly take care. Most of the elderly feel lonely. Opinion and past experience of elderly are not well come at all. Most of the family members are failed to satisfaction of elderly, Elderly not get proper take care, respected behaved, proper medication and company during lonely feelings. So most of the elderly are not satisfy regarding behavior of his family members.

So from this study it has been found that elderly people are increasing day by day, they are part of our family life, and nobody can avoid this life. Disability is also increasing due to improvement of public health. The suffering of elderly is painful, Loneliness is very pathetic, Elderly take care and respected well Behaved lack of our family life. Elderly life is not respected because they are old and backdated, they are excess in our family because they are dependable, diseased and old person.

As elderly life is a part of our life and old is gold and nobody can avoid this life naturally. So elderly person is our proud, and he is senior person in our family, he should get proper nursing, care and respect. We should think about elderly with morality. our moral duty is to try to solve the elderly problems. We should individually, Nationally and globally reanalyzed elderly problems and try to solve them.
References

1. Park K; Park textbook of preventive and social medicine 19th edition 2007 P 475

2. Chaklader $\mathrm{H}$; Ageing :Natural Process of Life, Bangladesh Journal of Geriatrics vol:41 ;October,2006

3. Rahman ASMA, Ahmed MF; Beggary at old age- an overview, Dhaka viswavidyalaya patrika, volume66, February 2000

4. Morgan L, Kunkel S; Aging The Social Context, Pine Forge Press, Calfornia, USA.

5. Ritchie, Mark A, Kathleen MS, Bowling T (eds); Uncertainty Rules Our Lives: The situation of older people in Bangladesh, Help Age International, Asia/pacific Regional Development center, Chiang My, Thailand.

6. International Institute on Aging ; Care giving and Older Persons-Gender Dimensions, Expert Group Meeting, 30 November -02 December 1997, Malta.

7. Ministry of Welfare ; Encyclopedia of Social Work in India (vol-iii), Government of India, New Delhi.

8. United Nation; Abuse of Older persons : recognizing and responding to abuse of older persons in a global context, Report of the Secretary -General, Item 3 of the provisional agenda, Economic and Social council, New York. United Nations, The Elderly and Family in Developing countries, Occational Papers Series, No.13, United Nations, Vienna.

9. Websites visited: http://www.globalising.org/elderrights/world/2004/ag eing.htm as viewed April 2008.

10. Rashid KM, Khabiruddin M and Hyder S; Text book of community medicine and public health 4 th edition. Dhaka RHM publisher 2004 reprinted 2003 P 518522 .

11. Ferdous F; BAAIGM and its services for the older people: my experiences in field practice, Bangladesh journal of geriatrics October,2006; 41:41-44

12. M. Kabir, M A Salam. The Effects of Various Interventions on the Welfare of the Elderly: Evidence from Micro-Study. Dhaka: Centre for Policy Dialogue (CPD) ,2001.

13. United Nations. 2007. World Population Ageing. New York: Population Division, DESA, United Nations. 
14. Kabir, Z.N. et al. Gender and rural-urban differences in reported health status of older people. Archives of Gerontology and Geriatrics, 2003; 37:77-91

15. Alfred de Souza. The social organization of ageing among the urban poor, New Delhi. Indian Social Instritute, 1982.

16. Khan MA. Family and ageing. Stress and reward in Pakistan. Paper presented at the Second Congress of the Asia/Oceanic Region of the International Association of Gerontology, Singapore, January 1983.
17. Toby B. Ageing around the world. Older people in the UK (1981-91). Ageing Int. 1993 June ; 20 (2):32-33. In Britain.

18. Suominen, M; Nutrition and Nutritional Care of Elderly People in Finnish Nursing Homes and Hospitals Department of Applied Chemistry and Micro-biology (Nutrition) University of Helsinki, Finland, Helsinki., 2007.

19. Patience,P. 2005, Aging. Available http://ask.healthline.com/galecontent/aging 